\title{
Możliwości stworzenia maski spawalniczej z komputerowym przetwarzaniem przestrzennego obrazu zamiast filtrów spawalniczych
}

\author{
The possibility of creating a welding mask with computer \\ processing of spatial image instead of welding filters
}

\section{Streszczenie}

W artykule przedstawiono możliwości zastąpienia maski spawalniczej z tradycyjnym filtrem optycznym na maskę spawalniczą wyposażoną w komputerowy system przetwarzania przestrzennego obrazu, umożliwiającą lepszą obserwację procesu spawania poprzez wyeliminowanie olśnienia wzroku spawacza, ułatwienie rozpoznawania granicy ciekłego jeziorka i poprawę widoczności krawędzi rowka. Ponadto wykorzystanie techniki rzeczywistości wzbogaconej pozwoli na przedstawianie dodatkowych informacji wspomagających proces spawania. W pracy omówiono metody analizy jakości płomienia i łuku spawalniczego, a także metody wykrywania granicy jeziorka oraz określenia głębokości wtopienia. Omówiono również nowoczesne metody filtracji obrazu pozyskanego z kamery cyfrowej oraz możliwości ich zastosowania w innowacyjnej masce spawalniczej z komputerowym przetwarzaniem obrazu.

Słowa kluczowe: spawanie, przetwarzanie obrazu, maska spawalnicza, filtr, jeziorko spawalnicze

\section{Abstract}

The article presents possibility of replacing of the welding mask with a traditional optic filter by a welding mask with a computer spacial image processing system, which enables a better observation of the welding process through the elimination of the eyes blinding, facilitation the recognition of the welding pool boundary, and improvement of the back bead edge visibility. Moreover, utilization of an augmented reality technic will allows to present the additional information supporting the welding process. This work discusses methods for the analysis of flame and welding arc as well as for the recognition of pool boundary and penetration depth. Furthermore, the article presents modern methods for a filtration of images collected from a digital camera as well as opportunities of their application in a building of the innovative welding mask with the computer analysis of 3D image.

Keywords: welding, image analysis, welding mas, filter, welding pool

\section{Wstęp}

\section{Wprowadzenie do techniki komputerowego wspomagania oceny procesu spawania}

W dzisiejszych czasach można kupić symulatory spawania, przy pomocy których spawacz widzi wirtualny obraz obszaru spawania i otrzymuje na monitorze wirtualny obraz spoiny. Przejście z takiego trenażera do rzeczywistego spawania nie jest jednak łatwe. Wynika to faktu, iż spawacza należy nauczyć interpretacji obrazu w taki sposób, aby widział on granicę jeziorka, której na kliszy fotograficznej nie można zobaczyć, ponieważ na granicy jeziorka ciekłego metalu jest taka sama temperatura i takie samo widmo. Z kolei dostrzeżenie rozgraniczenia pomiędzy cieczą a ciałem stałym wymaga analizy zmian szybkości narastania oświetlenia, wynikającej z różnej przewodności cieplnej metalu zakrzepniętego i metalu stopionego. Aby to przejście nie było tak trudne wystarczy zastąpić filtr spawalniczy wyświetlaczem obrazu przetwarzanego przez komputer. Kluczem do sukcesu jest tu postęp techniki tak zwanej rzeczywistości wzbogaconej (augmented reality [1]). Przy zastosowaniu tej techniki spawacz zamiast patrzeć wprost na miejsce spawania (co wymaga użycia ochronnej przyłbicy i odpowiedniego filtra optycznego) patrzy na wygodnie umieszczony przed jego oczami ekran komputera. Na ekranie tym dostępny jest przetworzony komputerowo obraz miejsca spawania oraz ewentualne dodatkowe informacje graficzne i alfanumeryczne, dołączane do tego obrazu przy użyciu wspomnianej wyżej techniki rzeczywistości wzbogaconej.

Jest to możliwe już dziś, kiedy ceny laptopów są porównywalne z ceną masek spawalniczych samoprzyciemniających z filtrami najwyższej jakości. Zapewne rozwój elektroniki i technik komputerowych sprawi, że relacje cenowe rozwiązań tradycyjnych (masek spawalniczych z filtrami) i nowatorskich rozwiązań opisywanych tutaj - będą jeszcze bardziej korzystne. Warto dodać, że rozwiązanie wykorzystujące

Prof. dr hab. inż. Ryszard Tadeusiewicz - Katedra Automatyki i Inżynierii Biomedycznej AGH, mgr inż. Ilona Jastrzębska - doktorant w Katedrze Ceramiki i Materiałów Ogniotrwałych AGH, mgr inż. Ryszard Jastrzębski - SKM Złotów. 
komputerowe przetwarzanie obrazu i rzeczywistość wzbogaconą daje możliwość informowania spawacza o głębokości wtopienia, temperaturze jeziorka i długości łuku. Dodatkowo można rozważyć możliwość informowania spawacza przez komputer, jakie ruchy należy wykonywać aby otrzymać lepszej jakości przetop lub lico spoiny. W poprzednich numerach Przeglądu Spawalnictwa prezentowano przedruki artykułów [2,3] zagranicznych informatyków zatrudnionych w spawalnictwie i artykuły wprowadzające polskich naukowców umożliwiające zrozumienie tych osiągnięć przez mechaników i budowlańców z historią komputerowego rozpoznawania obrazów w Polsce sięgającą lat 70-tych. Tym sposobem przygotowywano polskich inżynierów spawalnictwa do wejścia w tak wysoką technikę. Obecnie warto do tego zestawu wiadomości dodać informacje na temat rzeczywistości rozszerzonej, opisanej między innymi w pracy [1], której zastosowania do celów spawalniczych opisano między innymi w pracy [4].

\section{Komputerowe określenie jakości płomienia i łuku spawalniczego}

W 2004 roku japoński koncern zaprezentował pokazany na rysunku 1 system wizualny kontroli techniki spawania. System ten polegał na rejestracji za pomocą 4 kamer CCD procesu spawania wykonywanego przez spawacza. Kamery zostały rozmieszczone tak, aby rejestrować bezpośrednio proces spawania oraz aby zgromadzić jak najwięcej informacji na temat ruchów spawacza i parametrów wizualnych procesu spawania. Pierwsza kamera, zainstalowana przy masce spawalniczej, pozwoliła na rejestrację obrazu ciekłego jeziorka spawalniczego. Kolejna kamera miała za zadanie zarejestrować kąty podawania materiału dodatkowego, a kamera trzecia umieszczona od strony przetopu umożliwiła rejestrację wielkości ciekłego jeziorka przetopu, a także prędkości procesu spawania. Ostatnia kamera umieszczona w uchwycie spawalniczym pozwoliła na rejestrację wykonywanych przez spawacza ruchów uchwytem oraz dokładnego miejsca podawania drutu do jeziorka spawalniczego.

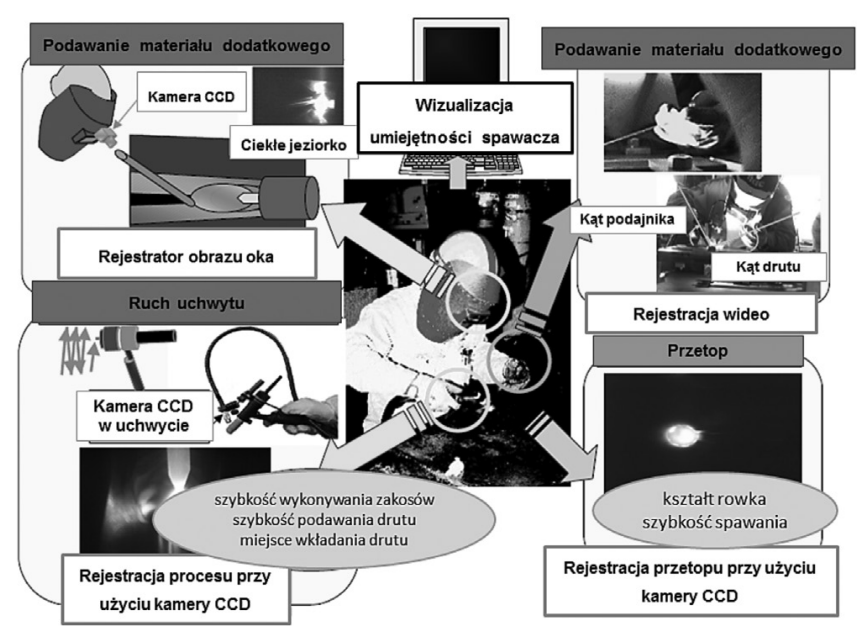

Rys. 1. Sposób rejestracji wizualnych parametrów spawania [5]

Fig. 1. The way for registration of the visual welding parameters

Zarejestrowany przy pomocy opisanego powyżej systemu proces spawania poddawany był analizie pod kątem wyznaczenia określonych parametrów spawania. Pokazany na rysunku 2 system analizy wyników pozwolił na przedstawienie w sposób wektorowy uzyskanych parametrów rzeczywistego spawania ręcznego oraz posłużył do wyznaczenia wektorowej "odległości” umiejętności spawania kursanta od umiejętności spawania eksperta. Porównanie istotnych parametrów spawania zostało szczegółowo przedstawione na rysunku 3. Tego typu system daje możliwość oceny poprawności wykonywania procesu spawania przez spawacza.

Wirtualne symulatory spawania firmy Lincoln Electric również dokonują oceny poprawności procesu spawania kursanta. Jednakże na obecną chwilę nie przekłada się to na rzeczywiste spawanie, gdyż osoba wyszkolona na wirtualnym symulatorze nie potrafi od razu właściwie wykonywać procesów spawania na rzeczywistym urządzeniu spawalniczym.

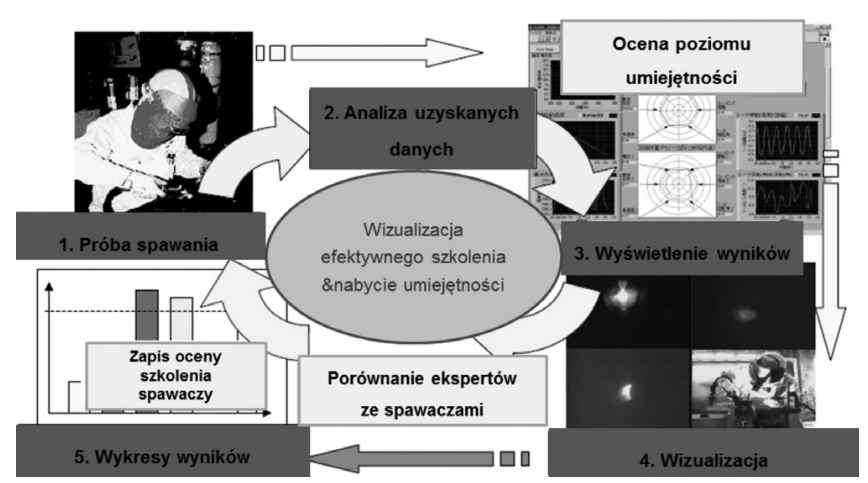

Rys. 2. Sposób wyznaczania różnicy w umiejętności spawania pomiędzy szkolonym a instruktorem w sposób wektorowy [5] Fig. 2. The method for determination of difference in welding skills between a trainee and an instructor showed in the vector way

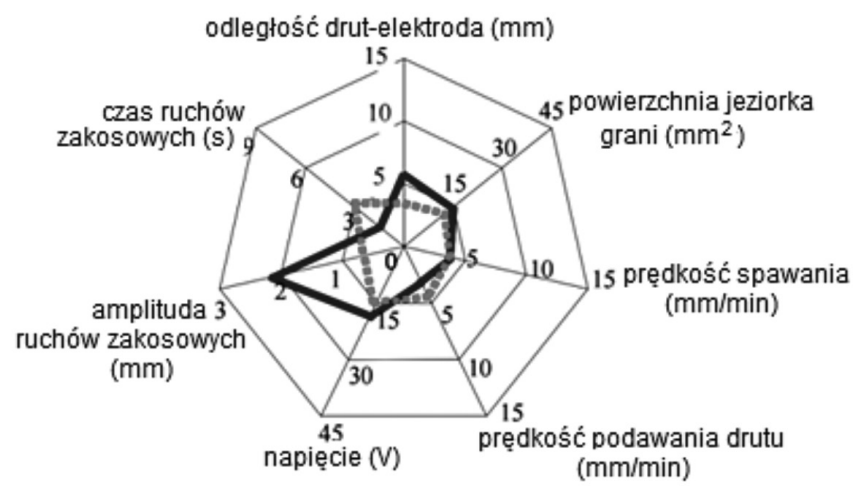

Rys. 3. Parametry wizualne spawania uzyskane przez kursanta i instruktora oraz wektorowa odległość kursanta od instruktora na początku i na końcu szkolenia; zależność przedstawiona kolorem czerwonym odnosi się do instruktora a niebieskim do spawacza [5] Fig. 3. The visual welding parameters obtained by a trainee and an instructor, and the vector distance of a trainee from an instructor in the initial and final stage of the training; relation depicted by red and blue color refers to an instructor and a trainee, respectively

Aby przejście od symulacji komputerowej do rzeczywistego spawania było możliwe należy typowy samoprzyciemniający filtr spawalniczy zastąpić wyświetlaczem komputerowym. Obraz na tym wyświetlaczu powinien być obrazem z kamery cyfrowej, obserwującej obszar spawania, wzbogaconym o obrazy związane z komputerowym przetwarzaniem obrazu jeziorka spawalniczego i łuku elektrycznego lub płomienia acetylenowo-tlenowego.

$\mathrm{Na}$ rysunku 4a przedstawiono obraz, jaki przekazał profesor informatyki Politechniki Wrocławskiej B. Cyganek i podwodny spawacz gazowy. Profesor ten w pracy [6] pokazał komputerowe przetwarzanie takiego jeziorka przy pomocy typowych funkcji oprogramowania do komputerowego przetwarzania obrazu. Badania prowadzono dla płomienia acetylenowo-tlenowego utleniającego i nawęglającego. Jak można to zaobserwować na rysunku możliwe jest 
a)
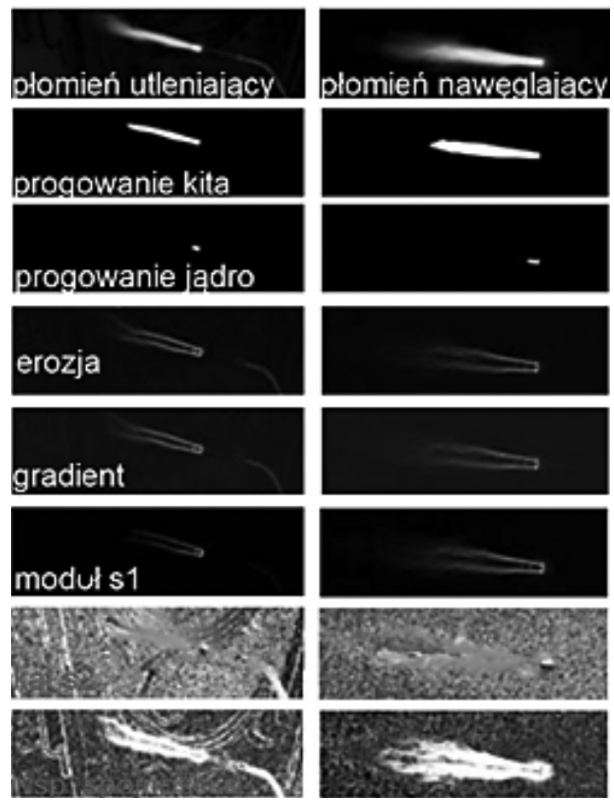

b)

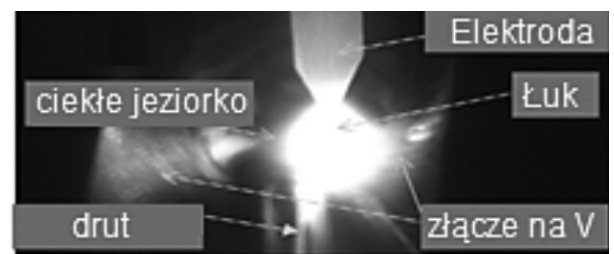

Amplituda/czas ruchów zakosowych Odległość elektroda-drut

Predkość podawania drutu

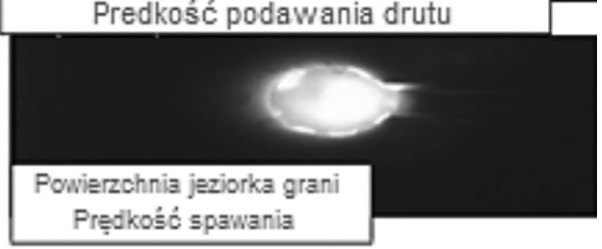

c)

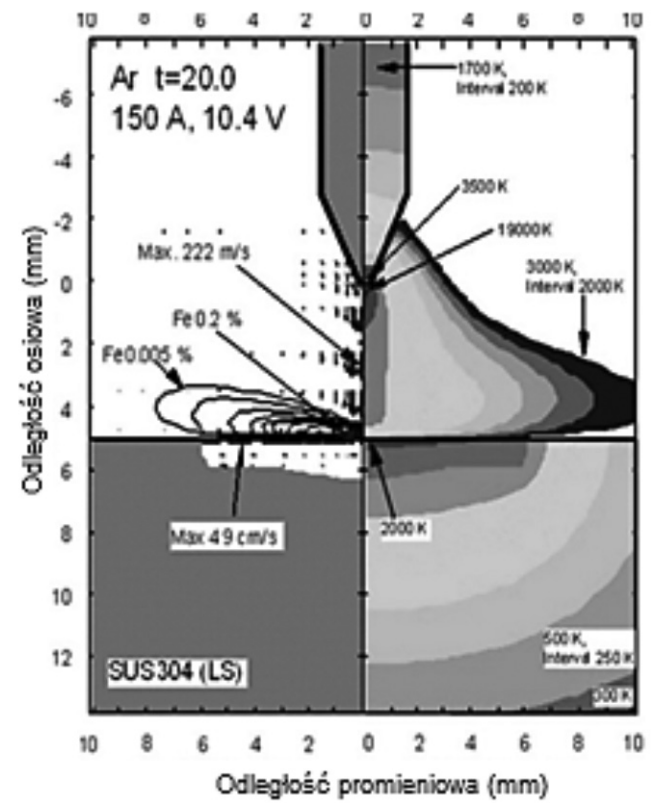

Rys. 4. Metody przetwarzania obrazu: a) wizualne dla płomienia [6], b) fizyczne dla łuku [5], c) obraz jeziorka i łuku TIG [7]

Fig. 4. Methods for the image analysis: a) visual for the flame [6], b) physical for the arc [5], c) image of the weld pool and the TIG arc

rozgraniczenie kity i jąderka płomienia, jednakże nie widoczna jest strefa odtleniająca.

Z kolei badacz $\mathrm{w}$ pracy [5] rysunku 4b przedstawił fotografię jeziorka spawalniczego pokazanego od strony grani i łuku przy spawaniu TIG. Na rysunku 4c pokazano przetwa- rzanie obrazu łuku przy pomocy metodologii obliczeniowej fizyków z Uniwersytetu Jagiellońskiego (optoelektronika i fizyka atomowa). Jak wynika z rysunku 4c metody fizyczne pozwalają na pozyskanie większej ilości informacji na temat rozkładów temperatur i oparów metali w łuku elektrycznym niż metody komputerowego przetwarzania obrazu, aczkolwiek nie są one aż tak szybkie.

\section{Komputerowe wykrywanie granicy jeziorka spawalniczego}

$\mathrm{Na}$ rysunku 5a,b pokazano odpowiednio lewy i prawy wzorzec oświetlenia jeziorka, a na rysunku 5 c na tle obrazu jeziorka spawalniczego przedstawiono komputerowo różnicę pomiędzy oświetleniem rzeczywistym a oświetleniem wzorcowym. Minimum określające najlepsze dopasowanie wzorca idealnie pokrywa się z granicą jeziorka spawalniczego, która została oznaczona krzyżykiem na rysunku. Skrajne minima przedstawione na wykresie (rys. 5d) pokazują kształt jeziorka spawalniczego. Opisana powyżej metodologia rozpoznawania jeziorka, która była wykorzystana w układzie badawczym do rozpoznawania kształtu jeziorka, pokazana na rysunku 5 e dla spawania aluminium i na rysunku $5 f$ dla stopów niklu, może być również przydatna do zastosowania w masce spawalniczej wyposażonej w komputerowy system przetwarzania przestrzennego obrazu. a)
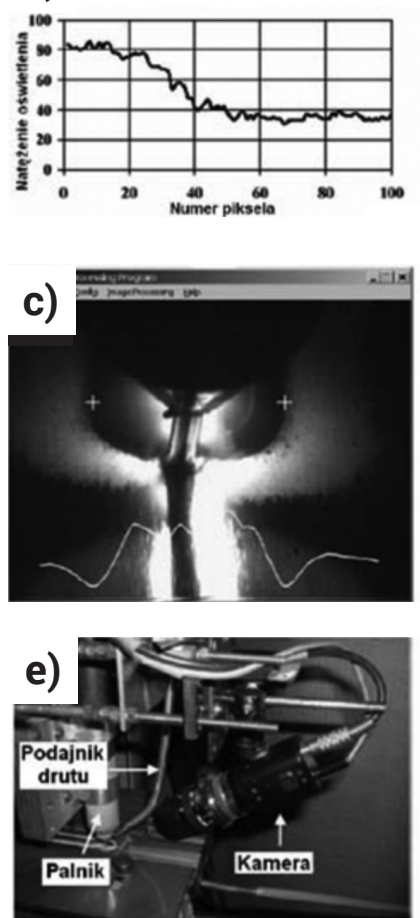

b)

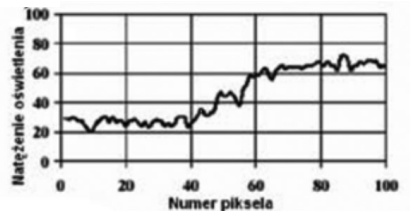

d)

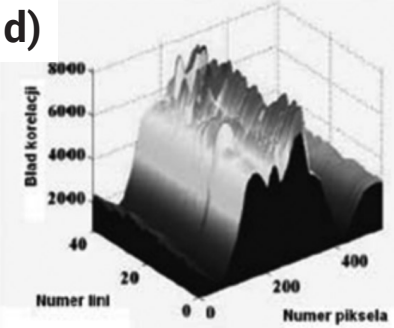

Rys. 5. Określenie granicy jeziorka metodą porównywania ze wzorcem: a) wzorzec oświetlenia lewej krawędzi, b) wzorzec oświetlenia prawej krawędzi, c) różnica pomiędzy oświetleniem i wzorcem z zaznaczonymi krzyżykami wskazującymi granice jeziorka, d) rozkład przestrzenny minimum pomiędzy rzeczywistym oświetleniem i wzorcem, e) ustawienie kamery przy spawaniu aluminium, f) ustawienia kamery przy spawaniu stopu niklu Inconel [2].

Fig. 5. Determination of the weld pool boundary by comparing with the standard: a) the standard light of the left edge, b) the standard light of the right edge, c) difference between the light and the standard light with the marked crosses indicating the weld pool boundary, d) spatial distribution of the minimum between real and ideal (standard) light, e) setting of the camera during welding of aluminum, f) setting of the camera during welding of Inconel nickel alloy 


\section{Komputerowe określenie ugięcia jeziorka spawalniczego}

W szkoleniu spawaczy bardzo ważne jest nauczenie przestrzennego widzenia jeziorka spawalniczego, które podlega zjawisku „uginania” ciśnieniem gorących gazów łuku. Wyjaśnienie spawaczom, że topienie materiału podczas procesu spawania nie odbywa się w wyniku przewodności cieplnej, ale fizycznego kontaktu gorących gazów ze spawanym metalem jest podstawą sukcesu.

Rysunek 6 pokazuje amerykańską metodologię obliczenia trzeciego wymiaru jeziorka ciekłego metalu (głębokości wtopienia).

Spawanie MAG z zastosowaniem pulsu może się odbywać przy cyklicznie zmieniającej się wartości prądu impulsowego. Pozwala to na odrywanie mniejszych kropel, lepszego ich nagrzewania i unikania rozprysków w wyniku różnicy temperatur pomiędzy kroplą a jeziorkiem.

Jak pokazuje rysunek 6 podczas trwania prądu impulsu ciekły metal jest odsuwany na boki, a gazy docierają coraz głębiej topiąc podłoże. Z kolei podczas trwania prądu bazy ciekły metal napływa do ugiętego jeziorka.

Poprzez pomiar ugięcia łuku pomiędzy prądem impulsu i bazy amerykańscy informatycy określili liniową zależność (pokazaną na rys. 6) pomiędzy różnicą ugięcia jeziorka a głębokością wtopienia przy spawaniu impulsowym MAG (135-P wg EN ISO 9606-1).

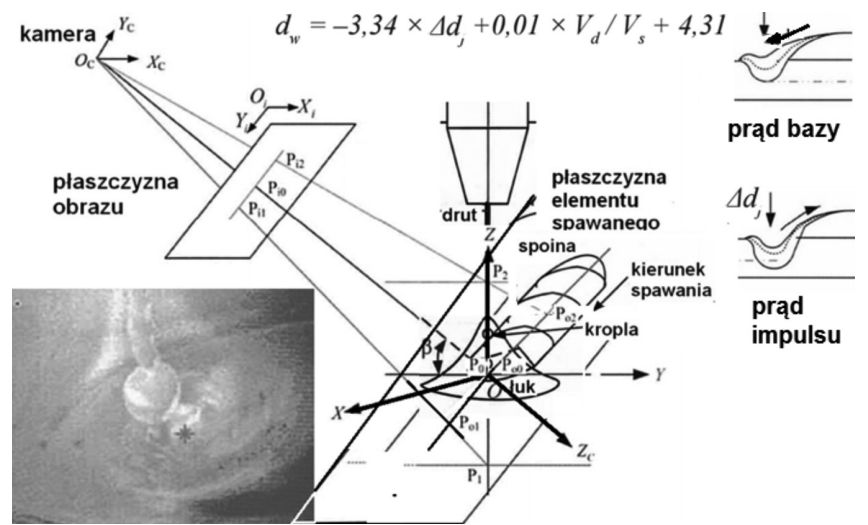

Rys. 6. Zasada pomiaru głębokości ugięcia powierzchni jeziorka spawalniczego i wyznaczenie zależności pomiędzy głębokością wtopienia $d_{w}$ a różnicą pomiędzy ugięciem jeziorka podczas prądu impulsu i prądu bazy $\Delta$ dj przy spawaniu MIG/MAG oraz stosunkiem szybkości podawania drutu $\mathrm{Vd}$ a prędkością spawania $\mathrm{V}_{\mathrm{s}}$ [3].

Fig. 6. The principle of measuring the welding pool surface depth, together with determination of the relationship between penetration depth $d_{w}$ and difference between surface depth during peak and base current $\Delta \mathrm{dj}$ for MIG/MAG, and ratio of wire feed speed to travel speed $V_{s}$

Przy spawaniu zwarciowym i natryskowym należy jeszcze brać pod uwagę położenie łuku w stosunku do jeziorka i rozkład składowej ciśnienia łuku na składową prostopadłą uginającą jeziorko i składową poziomą transportującą metal z topionego drutu do jeziorka przy spawaniu w lewo lub do nadlewu przy spawaniu w prawo.

\section{Nowe metody filtracji komputerowej obrazu}

Wprowadzenie kamery cyfrowej jako elementu obserwującego obszar spawania oraz monitora cyfrowego jako miejsca, na którym spawacz obserwuje efekty swojej pracy, doprowadziło do tego, że możliwa stała się komputerowa (obliczeniowa) filtracja obrazu pozyskiwanego z kamery przed jego zaprezentowaniem człowiekowi. Metody komputerowej filtracji obrazu opisano między innymi w książce [8] i do niej odsyłamy czytelników zainteresowanych szczegółami. Tu natomiast warto wskazać kilka celów i kilka metod komputerowej filtracji i przetwarzania obrazów, które mogą być szczególnie przydatne w zadaniu polepszenia warunków obserwacji jeziorka płynnego metalu i obszaru spawania.

Pierwsze zadanie, które można powierzyć komputerowemu systemowi przetwarzania obrazu może polegać na poprawie jakości obrazu i usunięciu z niego zakłóceń, których źródłem jest między innymi łuk spawalniczy lub płomień palnika. Jaskrawo świecące źródła ciepła używane przy spawaniu powodują, że obserwując obraz przez tradycyjny samoprzyciemniający filtr optyczny mamy równomierne przyciemnienie zarówno obrazu łuku (lub płomienia) jak również miejsca spawania i jego okolicy. Powoduje to, że wprawdzie łuk czy płomień nie powodują olśnienia wzroku spawacza, ale jednocześnie to, co powinno być dokładnie obserwowane (miejsce powstawania spoiny) jest widoczne znacząco gorzej, co może wpływać niekorzystnie na dokładność pracy spawacza. W sytuacji gdy pomiędzy źródłem obrazu (kamerą cyfrową) a miejscem prezentacji obrazu (wyświetlaczem przeznaczonym dla spawacza) jest komputer wyposażony w możliwość cyfrowego przetwarzania obrazu - jest możliwe zastosowanie zróżnicowanego w różnych obszarach skalowania amplitudy (jasności) obrazu, co pozwoli dowolnie stłumić blask łuku spawalniczego lub płomienia używanego palnika, tak żeby nawet drobne zmiany jasności w obrębie jeziorka płynnego metalu i obszaru tworzenia spoiny mogły być zaobserwowane i w pełni wykorzystane przez spawacza. W szczególności metodą przetwarzania obrazu, jaka może być w tym miejscu zastosowana, może być lokalne (w sensie poszczególnych regionów obrazu pola widzenia spawacza) zastosowanie techniki równoważenia histogramu.

Kolejna metoda komputerowego przetwarzania obrazu, jaka może być użyta podczas filtracji obrazu obserwowanego i wykorzystywanego przez spawacza, związana jest z możliwością nieliniowego przekształcania amplitudy wizyjnego sygnału wejściowego przed jego zaprezentowaniem na wyświetlaczu wyjściowym spawaczowi. Typowe przetworniki optoelektroniczne (najczęściej matryce CCD) używane w kamerach cyfrowych pozwalają na odwzorowanie jasności każdego punktu (czyli każdego piksela na obrazie) z dokładnością przynajmniej ośmiobitową. Przy takiej rozdzielczości amplitudowej (jeden bajt na piksel) kamera jest w stanie zarejestrować 256 rozróżnialnych poziomów jasności obrazu, podczas gdy badania psychologii percepcji człowieka pokazują, że spawacz może (w najlepszym przypadku) rozróżnić swoim wzrokiem najwyżej 60 poziomów jasności. Odpowiednio dobierając więc sposób przekształcenia (zwykle nieliniowego) 256 poziomów jasności pikseli rejestrowanych przez kamerę na niespełna 60 poziomów jasności prezentowanych na monitorze odbiorczym można sprawić, że tam, gdzie jest to potrzebne, można zróżnicować w sposób dostrzegalny dla człowieka nawet niewielkie zmiany jasności niosące na przykład informację o granicy pomiędzy jeziorkiem płynnego metalu a jeszcze nie przetopionym fragmentem spawanej konstrukcji. Gołym okiem te zmiany jasności mogą być niedostrzegalne, zatem spawacz obserwujący proces spawania za pośrednictwem cyfrowego systemu przetwarzania obrazu może uzyskać znacząco więcej informacji, niż gdyby obserwował ten proces bezpośrednio, nawet przez najdoskonalsze i najnowocześniejsze filtry ulokowane w typowej masce ochronnej. 
Cyfrowe przetwarzanie obrazu daje zresztą o wiele więcej możliwości, związanych między innymi z automatycznym wyznaczaniem granic widocznych obiektów (np. kropli płynnego metalu) i granic łączonych elementów. Te granice i krawędzie obserwowane gołym okiem (oczywiście przez odpowiednie filtry) mają często nieostry lub rozmyty charakter ze względu na wysoką temperaturę panującą w strefie spawania i związane z tym trudności obserwacji. Badacze zajmujący się komputerowym przetwarzaniem obrazów znaleźli jednak metody poprawy jakości takich obrazów. Cały zestaw takich metod znaleźć można między innymi w rozprawie doktorskiej [9]. Pogłębione naukowe opracowanie na temat tych metod (pozwalających nawet na ocenę położenia granic obiektów z dokładnością sub-pikselową) znaleźć można w pracy [10]. Łączenie rzeczywistego (ewentualnie poddanego filtracji) obrazu obszaru roboczego spawacza z wynikami jego zaawansowanego przetwarzania (na przykład z lokalizacją granic i detekcją krawędzi) odbywać się może przy zastosowaniu techniki rzeczywistości rozszerzonej, w której przed prezentacją obrazu człowiekowi (spawaczowi) następuje dołączenie do niego elementów graficznych będących efektem wspomnianego wyżej przetwarzania.

Rzeczywistość rozszerzona daje także możliwość dodawania do obrazu elementów tekstowych. Dzięki temu obok technik filtracji obrazu, które mogą być zastosowane przy wykorzystaniu maski spawalniczej z komputerowym przetwarzaniem przestrzennego obrazu zamiast filtrów spawalniczych, szerokie zastosowanie mogą mieć zaawansowane techniki analizy obrazu. Możliwe jest wyznaczanie (i podawanie do wiadomości spawacza) wyników pomiarów różnychwymiarówliniowych,powierzchniowychi(estymowanych)objętościowychwidocznychnaobrazieelementów,możliwe jest wykrywanie sytuacji nieprawidłowych (na przykład zbyt szybki ruch) wraz z generowaniem i wyświetlaniem na ekranie ostrzeżeń lub sugestii dla spawacza, możliwe jest włączenie na tym etapie także informacji związanych z uczeniem początkującego spawacza - ale o tym będzie mowa w kolejnym rozdziale.

\section{Maska spawalnicza z komputerowym przetwarzaniem przestrzennego obrazu jako trenażer koordynacji ruchu z obserwacją}

Sprawa treningu spawaczy jest zagadnieniem trudnym i zdecydowanie wymagającym udoskonalenia. Na rysunku 7 pokazano, jak robi się to obecnie. Konkretnie przedstawiono na tym rysunku aktualnie używaną obrazkową instrukcję fizyki spawania, stosowaną do szkolenia spawaczy z umysłem ścisłym. Okazuje się, że poprzez wydawanie szkolonym spawaczom poleceń ustnych w zakresie techniki spawania można nie tylko doszkolić spawaczy, ale także zaprogramować ich do koordynacji ruchu z obserwacją podczas spawania. Korzystając z tych opisów można wykonać algorytmy „podpowiadania” spawaczowi jakie ruchy ma wykonać, aby poprawić technikę spawania. Główna trudność w szkoleniu spawaczy polega na tym, że człowiek steruje rękami myśląc automatycznie fizyką wody a nie fizyką ciekłego metalu. Obserwacja ta pozwoliła na analizowanie zarejestrowanych ruchów spawacza, obrazu jeziorka, a nawet napięcia mięśni spawacza. Badacze angielscy skupili się na uczeniu komputerów predyspozycji do spawania czyli wykrywania granicy jeziorka, której nie widzi kamera. Przykład (1) tego rysunku ilustruje głębokość wtopienia w zależności od odległości źródła ciepła i pokazuje, że do uzyskania głębszego wtopienia

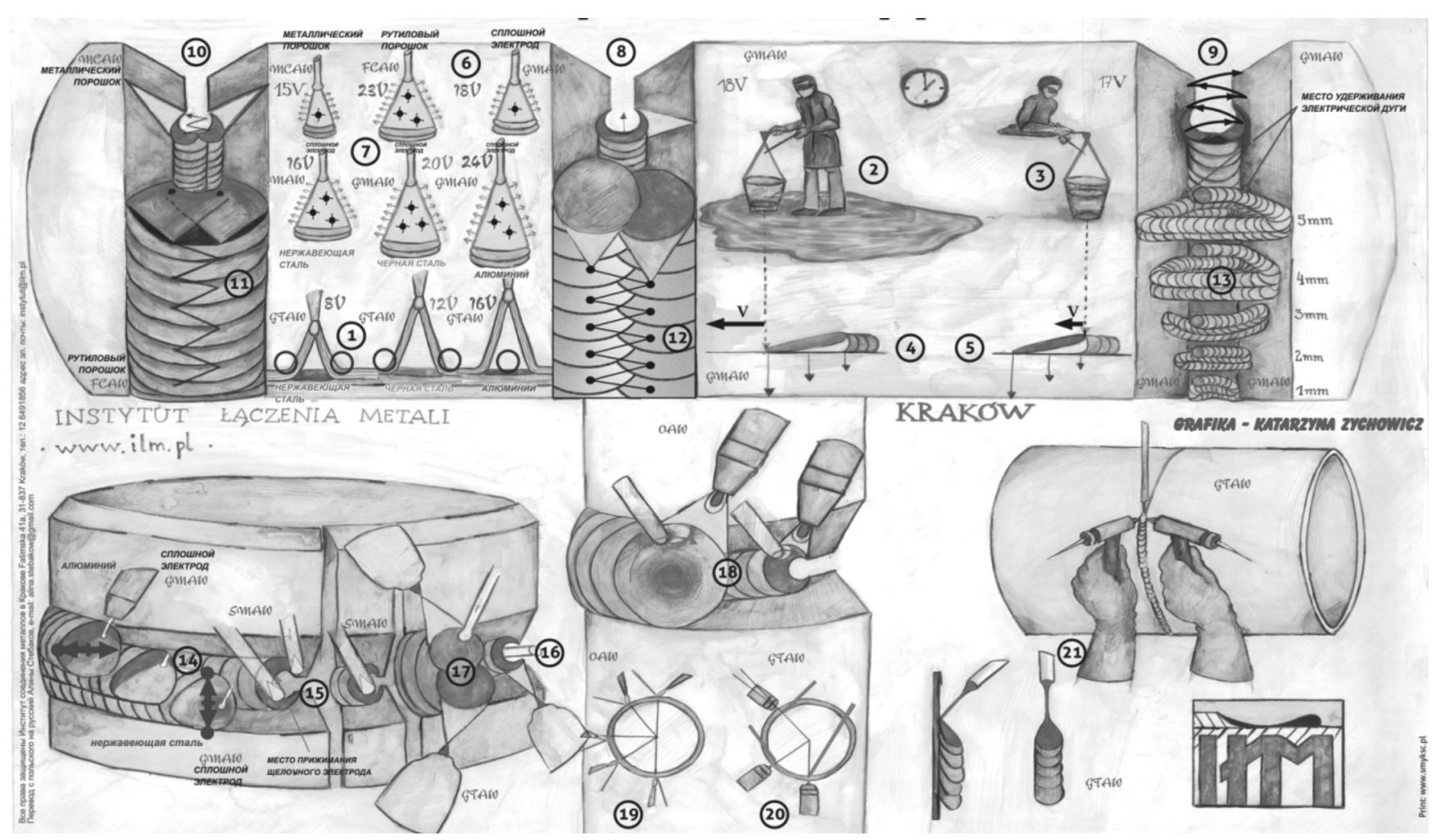

Rys. 7. nstrukcja obrazkowa spawania (oznaczenia na rysunkach: MCAW- spawanie drutem proszkowym metalicznym, FCAW- spawanie drutem proszkowym topnikowym, GMAW- spawanie drutem pełnym, SMAW- spawanie elektrodą otuloną, OAW- spawanie acetylenowo-tlenowe, GTAW- spawanie TIG)

Fig. 7. Image welding instruction (designations at the images: MCAW - welding with a metal-cored electrode wire, FCAW - welding with a flux-cored metal electrode, GMAW - welding with a solid wire, SMAW - welding with a covered metal electrode, OAW - oxy-acetylene welding, GTAW - TIG welding) 
należy przybliżyć źródło ciepła. Przybliżenie źródła ciepła do topionego metalu jednocześnie obniża temperaturę ciekłego metalu ciepłem topienia, a odsunięcie źródła ciepła nagrzewa jeziorko ciekłego metalu przewodnością cieplną. Przykłady (2) i (3) pokazują, że duże jeziorko jest płytkie i "gorące" (tzn. o wyższej temperaturze), natomiast małe jeziorko jest głębokie i "zimne” (tzn. o niższej temperaturze). Przykłady (4) i (5) wyjaśniają, że szybszy ruch źródła ciepła powoduje uzyskanie głębszego wtopienie, natomiast wolniejszy ruch palnika zapewnia otrzymanie mniejszego wtopienia i nagrzanie jeziorka spawalniczego. Wynika z tego, że przy większym natężeniu prądu należy wykonywać szybsze ruchy zakosowe, a materiał o mniejszej przewodności cieplnej należy spawać krótszym łukiem niż materiał o większej przewodności cieplnej.

Z przykładów przedstawionych na rysunku wynika na przykład to, że krople ciekłego metalu przy spawaniu stali nierdzewnej, tzn. materiału o mniejszej przewodności cieplnej, należy dodawać po bokach (aby zatrzymać topienie i dłużej nagrzewać materiał podłoża). Natomiast w przypadku spawania aluminium, tj. metalu o większej przewodności cieplnej, krople należy dodawać w środku jeziorka (aby nie zatrzymywać topienia i ochłodzić jeziorko ciekłego metalu). Z tego wynika różnica w kierunku ruchów zakosowych przy spawaniu stali metodą MAG i przy spawaniu aluminium metodą MIG. Jednak mimo poglądowości instrukcji w formie pokazanej przykładowo na rysunku 7, nauka spawania jest sprawą trudną i czasochłonną.
Wprowadzenie do użytku maski spawalniczej z komputerowym przetwarzaniem przestrzennego obrazu daje także w tym zakresie nowe cenne możliwości. W szczególności daje możliwość stałego porównywania działania szkolonego spawacza z obrazami i sekwencjami wideo zarejestrowanymi komputerowo w momencie, kiedy wymagane czynności wykonywał doświadczony spawacz (instruktor, mistrz którego należy naśladować). Komputer w takim przypadku wspomaga proces bieżącej obserwacji działań spawacza przez niego samego (wykorzystując techniki omówione w poprzednim rozdziale), ale także może sygnalizować odstępstwa od optymalnej procedury, wykrywane poprzez konfrontację aktualnego działania ucznia z zapamiętanym działanie wzorcowym (instruktora). Informacja o wykrywanych nieprawidłowościach może być wyświetlana (w formie tekstowej lub graficznej) na tym samym monitorze ucznia, na którym on sam śledzi przeprowadzany proces technologiczny i skutki własnych działań (będzie to oczywiście rzeczywistość rozszerzona). Możliwe jest także ostrzeganie głosowe ucznia za pomocą dołączonego do komputera syntezatora mowy.

Cały proces szkolenia może być śledzony na dodatkowym monitorze przez jednego lub kilku instruktorów, którzy mogą dodawać swoje rady w trakcie procesu nauki spawania albo po jakimś zakończonym etapie serii zaplanowanych treningów. Co więcej, ze szkoleń takich może być automatycznie sporządzana różna dokumentacja.

\section{Wnioski}

Nowe techniki komputerowego przetwarzania obrazu wraz z możliwościami, jakie dostarcza technika rzeczywistości rozszerzonej powodują, że w niedalekiej przyszłości tradycyjne maski spawalnicze, przyłbice i filtry optyczne zastąpione zostaną komputerowym torem wizyjnym. W takim (opisanym w pracy) torze wizyjnym obraz miejsca spawania i narzędzi spawalniczych nie tylko będzie elektronicznie pozyskiwany i po komputerowej obróbce przedstawiany do wzrokowej oceny przez spawacza, ale dodatkowo będzie analizowany przez odpowiednie programy komputerowe. W wyniku tej analizy mogą powstawać oceny ilościowe (na przykład głębokości jeziorka płynnego metalu albo jego temperatury) niemożliwe do uzyskania przy pomocy tradycyjnej wzrokowej oceny. Co więcej, porównując komputerowo rejestrowany przebieg aktualnego procesu spawania, wykonywanego przez spawacza, z przebiegami zapamiętanymi w trakcie procesu uczenia - można korzystając z tej samej techniki rzeczywistości rozszerzonej udzielać spawaczowi rad i wskazówek, doskonaląc jego pracę i zapobiegając powstawaniu błędów, których skutki są później trudne do usunięcia.

\section{Literatura}

[1] K. Lee: "Augmented Reality in Education and Traning. TechTrends", vol. 56, nr 2, marzec/kwiecień 2012, s. 13-21.

[2] W. Lucas, J. Smith, C. Balfor, D. Bertaso, G.Melton: "Wizyjna kontrola rozmiaru jeziorka spawalniczego w czasie rzeczywistym", Przegląd Spawalnictwa, nr 1, 2009, s. 11-16.

[3] Z. Wang, Y. M. Zhang, L.Wu: "Pomiar i określenie ugięcia powierzchni jeziorka spawalniczego oraz głębokości wtopienia spoiny w pulsacyjnym spawaniu MIG/MAG", Przegląd Spawalnictwa, nr 3, 2013, s. 27-37.

[4] S. Mann, R. Chun Hing Lo, K. Ovtcharov, S. Gu, D. Dai, C. Ngan, T. Ai: "Real Time HDR (High Dynamic Range)" Video for EYETAP Wearable Computers, FPGA-Based Seeing Aids, and GLASSEYES (EYETAPS), 25th IEEE Canadian Conference on Electrical and Computer Engineering (CCECE), 2012

[5] M. Sukamu, R. Tsuboi, K. Kubo, S. Asai: "Development of welders training suport system with visual sensors, Dokument Międzynarodowego Instytutu Spawalnictwa IIW nr XII-1813-04, Materiały konferencji IIW w Osace 2004, s. 103-108.
[6] R. Jastrzębski, B. Cyganek, J. Przytuła, I. Jastrzębska, K. Szczyrbak: "Wyszkolenie fizyczne spawaczy i lutowaczy gazowych kluczem do kopiowania ruchów spawacza na ruchy robota", Dozór Techniczny, nr 4-5, 2014, s.74-82.

[7] A. Murphy: „Wpływ oparów metalicznych na spawanie łukowe. Cz.3 Modelowanie łuku spawalniczego-wyniki. Dymy spawalnicze", Przegląd Spawalnictwa, nr 11, 2012, s.3-11.

[8] R. Tadeusiewicz, P. Korohoda: "Computer analysis and image processing [in Polish: Komputerowa analiza i przetwarzanie obrazów], Progress of Telecommunication Foundation Publishing House, Krakow, 1997.

[9] A. Fabijańska: "Algorytmy poprawy jakości obrazów w wysokotemperaturowych pomiarach właściwości fizyko- chemicznych wybranych metali i ich stopów, rozprawa doktorska na Politechnice Łódzkiej, data obrony - grudzień 2007.

[10] A. Fabijańska: "A survey of subpixel edge detection methods on images of heat-emitting metal specimens", International Journal of Applied Mathematics and Computer Science, vol. 22, no. 3, 2012, str. 695-710. 